\title{
Efficient synthesis of cRGD functionalized polymers as building blocks of targeted drug delivery systems
}

\author{
Hajeeth Thankappan ${ }^{\mathrm{a}}$, Aykut Zelcak ${ }^{\mathrm{a}, \mathrm{b}}$, Damla Taykoz ${ }^{\mathrm{c}}$, Volga Bulmus ${ }^{\mathrm{a}, *}$ \\ ${ }^{a}$ Department of Bioengineering, Izmir Institute of Technology, Urla, Izmir 35430, Turkey \\ b Biotechnology and Bioengineering Graduate Program, Izmir Institute of Technology, Urla, Izmir 35430, Turkey \\ ${ }^{c}$ Department of Chemical Engineering, Izmir Institute of Technology, Urla, Izmir 35430, Turkey
}

\section{A R T I C L E I N F O}

\section{Keywords:}

RGD

RAFT polymerization

End-group functionalization

Targeted drug delivery

\begin{abstract}
A B S T R A C T
Synthetic peptides with cyclic arginine-glycine-aspartate motif (cRGD) play an important role in cell recognition and cell adhesion. cRGD-decorated soluble polymers and polymeric nanoparticles have been increasingly used for cell-specific delivery of antitumor drugs. While the significance of cRGD modification for tumor cell-specific targeting of polymeric carriers is well-accepted, straightforward procedures ensuring the fidelity of cRGD modification of polymeric systems are still lacking. Herein, we have reported an in-situ polymerization approach for synthesis of cRGD-end-functionalized well-defined polymers as potential building blocks of targeted drug delivery systems. A new cRGD peptide functionalized RAFT agent was synthesized as confirmed by MALDI-TOF and ${ }^{1} \mathrm{H}$ NMR spectroscopy. The ability of this RAFT agent to control polymerizations was then tested using two different monomers oligoethyleneglycol acrylate and t-butyl methacrylate. The RAFT-controlled character of polymerizations and the living characteristic of the synthesized polymers were investigated through a series of kinetic experiments. The cytotoxicity and targeting capability of cRGD-functionalized OEGA polymers were investigated using cell lines expressing $\alpha_{v} \beta_{3}$ integrins at varying extents.
\end{abstract}

\section{Introduction}

Among various targeting peptides, the cyclic arginine-glycine-aspartate (cRGD) motif plays an important role in cell recognition and cell adhesion in cancer diagnosis and treatment as it has selective affinity for $\alpha_{\mathrm{v}} \beta_{3}$ integrins that are highly expressed on tumoral endothelial cells as well as many tumor cells, including osteosarcomas, glioblastomas, melanomas, and carcinomas of lung and breast [1-15]. Accordingly, cRGD peptide conjugated polymers and lipids have been widely used for delivering anti-cancer chemotherapeutics, genes and contrast agents to tumor cells overexpressing $\alpha_{v} \beta_{3}$ integrin receptors $[4,5,9]$.

RGD-binding site is a composite binding site in integrins made of $\alpha$ and $\beta$ subunits. The guanidine functional group of arginine residue in RGD motif is engaged in a bidentate salt bridge with a highly conserved aspartic acid residue present in the $\alpha$ subunit of the receptor. The carboxylate group of aspartic acid residue of RGD peptide interacts with the metal-ion dependent adhesion site which is located in $\beta$ subunit of the receptor [16]. Numerous work has been reported for targeting drugs to tumors using cRGD peptide [17-25]. cRGD decorated polymeric micelles, nanoparticles and soluble polymers have been widely used for targeted delivery of anticancer therapeutics [6-30]. The most common approach to prepare cRGD-functionalized polymeric systems for targeting tumor cells involves the conjugation of cRGD to pre-made polymers with functional end-group or to micelle corona [21,31-35]. However in general the post-polymerization conjugation of peptides to polymers or micelles has the disadvantage of poor conjugation efficiency due to steric hindrance problems and more importantly it usually yields poorly-defined, heterogeneous systems depending on the conjugation yields. Practicality of this approach may also be limited as it requires an excess amount of peptide and tedious purification steps [36]. In the case of conjugating short targeting peptides such as cRGD (which consists of 4-5 amino acid residues) to polymers or polymeric systems (such as micelles), it is common to obtain a mixture of nonconjugated and conjugated polymers/polymeric systems as it is usually not possible to separate the peptide-conjugated polymers from the nonconjugated ones via simple purification techniques due to the short sequence of the peptide, which leads to poorly-defined drug carriers. All these disadvantages and limitations affect the targeting efficacy of the delivery system and also make the establishment of structure-activity correlations impossible.

In order to improve the quality of targeted drug delivery systems based on polymers, the controlled radical polymerization (CRP)

\footnotetext{
* Corresponding author.

E-mail address: volgabulmus@iyte.edu.tr (V. Bulmus).
} 
techniques which have proved to improve the conjugation yield, reduce the heterogeneity in the biomolecule-polymer conjugate and minimize purification steps [37-41] would be useful. Considering the importance and common usage of cRGD peptide as a cell-specific targeting moiety in cancer therapy and diagnosis, we propose an in-situ polymerization/ conjugation approach to synthesize cRGD-functionalized well-defined polymers as potential building blocks of targeted drug/gene/contrast agent carrier systems. To the best of our knowledge, an in-situ polymerization approach has not been applied to the synthesis of cRGDfunctionalized polymers. The approach utilizes RAFT polymerization which was successfully applied to the in-situ synthesis of proteinpolymer conjugates [42] as well as polymers with carboxyl [43], hydroxyl [44], imidazole [45], acetal [46], biotin ester [47] and sugar [48] end moieties. Accordingly, a new cRGD peptide functionalized RAFT agent was synthesized and then tested using two different monomers oligoethyleneglycol acrylate and t-butyl methacrylate. The RAFT-controlled character of polymerizations and the living characteristic of the synthesized polymers were demonstrated. The cytotoxicity as well as the targeting capability of cRGD-functionalized polymers were further investigated using cell lines expressing $\alpha_{v} \beta_{3}$ integrins at varying extents. The results are discussed below.

\section{Experimental section}

\subsection{Synthesis of 4-cyano-4-(ethylsulfanylthiocarbonyl) sulfanyl pentanoic} acid (1)

4-Cyano-4-(ethylsulfanylthiocarbonyl) sulfanyl pentanoic acid was synthesized according to the procedure shown in Scheme 1. Synthetic method was adapted from Moad et al. [49]. The crude ECT was isolated by column chromatography using silica gel as the stationary phase and 60:40 ethyl acetate: hexane as the eluent (\% yield, 60\%).

${ }^{1} \mathrm{H}$ NMR (CDCl3, $\delta$ in ppm): 1.38 (t, SCH2CH3), 1.88 (s, CCNCH3), 2.40-2.70 (m, CH2CH2), 3.33 q (q, SCH2CH3).

\subsection{Synthesis of cRGD modified 4-cyano-4-(ethylsulfanylthiocarbonyl) sulfanyl pentanoic acid}

Synthesis of cyclic RGD modified RAFT agent involves a two-step process.

\subsubsection{4-Cyano-4-ethylsulfanylthiocarbonylsulfanyl-4-methyl-butyric acid} 2,5-dioxo-pyrrolidin-1-ylester (active ester) (2)

The first step involves activation of 4-cyano-4-(ethylsulfanylthiocarbonyl) sulfanyl pentanoic acid $(0.19 \mathrm{mmol})$ ) using $\mathrm{N}, \mathrm{N}$,-dicyclohexylcarbodiimide $(0.28 \mathrm{mmol})$ and $\mathrm{N}$-hydroxysuccinimide $(0.29 \mathrm{mmol})$ as activating reagent in dichloromethane $(5 \mathrm{ml})$ as solvent for $10-12 \mathrm{~h}$ at room temperature, reaction progress was monitored by thin layered chromatography using dichloromethane as the eluent. The dicyclohexylurea (DCU) by-product was filtered off. The filtrate was evaporated to dryness under vacuum to give a crude product, which was then taken up in $2 \mathrm{ml}$ of dichloromethane. The insoluble solid was filtered off. $5 \% n$-Hexane was then added to the filtrate that still contained insoluble product (dicyclohexylurea) and stored in freezer overnight and filtered. The filtrate was concentrated and slurried in diethyl ether $(2 \mathrm{ml})$ to give the titled product as a yellow solid $(0.068 \mathrm{~g}$, Yield: $83 \%)$.

${ }^{1} \mathrm{H}$ NMR (DMSO, $\delta$ in ppm): 1.27 (t, $\mathrm{SCH}_{2} \mathrm{CH}_{3}$ ), 1.86 (s, $\mathrm{CCNCH}_{3}$ ), 2.50-2.90 (m, $\mathrm{CH}_{2} \mathrm{CH}_{2}$ ), 2.8 (s, $\mathrm{COCH}_{2} \mathrm{CH}_{2} \mathrm{CO}$ ), 3.38 (q, $\mathrm{SCH}_{2} \mathrm{CH}_{3}$ ).

\subsection{2. cRGD modified 4-cyano-4-(ethylsulfanylthiocarbonyl) sulfanyl pentanoic acid (3)}

Second step involves the reaction of cRGD with previously prepared 4-cyano-4-ethylsulfanylthiocarbonylsulfanyl-4-methyl-butyric acid 2,5dioxo-pyrrolidin-1-yl ester (active ester) in N'N-dimethylformamide (DMF) $(2.5 \mathrm{ml})$ at $5-25^{\circ} \mathrm{C}$. Briefly, DMF $(2.5 \mathrm{ml})$ was added to the solution of 4-cyano-4-ethylsulfanylthiocarbonylsulfanyl-4-methyl-butyric acid 2,5-dioxo-pyrrolidin-1-yl ester $(0.000138 \mathrm{mmol})$, cRGD peptide $(0.000138 \mathrm{mmol})$ in DMF $(2.5 \mathrm{ml})$ was added slowly dropwise over a period of $10-15 \mathrm{~min}$ at $5-10{ }^{\circ} \mathrm{C}$. The reaction mass was then warmed to room temperature and allowed to stir for $12 \mathrm{~h}$. After $12 \mathrm{~h}$, the organic layer was concentrated up to 1-2 vol stage under high vacuum below $35^{\circ} \mathrm{C}$, slowly added $2 \mathrm{ml}$ of diethyl ether and filtered through Buchner funnel. The crude product was purified by slurry wash with diethyl ether $(2 \mathrm{ml})$, dichloromethane $(5 \mathrm{ml})$ and chilled THF: water (10:1) mixture $(2 \mathrm{ml})$ and vacuum dried. The product was collected as yellow solid $(0.06 \mathrm{~g}$, Yield: $65 \%)$ and characterized using mass spectrometry and NMR. Theoretical mass of cRGD modified RAFT agent is 848.61. The MS analysis indicated mainly the presence of a compound with $[\mathrm{M}+\mathrm{H}]^{+}$of 849.8 , which confirms well the synthesis of cRGD modified RAFT agent.

${ }^{1} \mathrm{H}$ NMR (DMSO, $\delta$ in ppm): 3.0-3.1 (q, $2 \mathrm{H}, \mathrm{SC}_{2} \mathrm{CH}_{3}$ ), 1.75-1.80 (s, $3 \mathrm{H}, \mathrm{CCNCH}_{3}$ ), 2.0-2.4 (m, 4H, $\left.\mathrm{CCNCH}_{3} \mathrm{CH}_{2} \mathrm{CH}_{2} \mathrm{CONH}\right), 1.0-1.30$ (t, $3 \mathrm{H}, \quad \mathrm{SCH}_{2} \underline{\mathrm{C}}_{3}$ ), $1.0-1.25$ (m, $2 \mathrm{H}, \quad \mathrm{NHCOCHCH}_{2} \mathrm{CH}_{2} \mathrm{CH}_{2} \mathrm{CH}_{2} \mathrm{NH}$ ), 1.25-1.75 (m, 4H, NHCOCHC $\left.{ }_{2} \mathrm{CH}_{2} \mathrm{CH}_{2} \mathrm{CH}_{2} \mathrm{NH}\right), 1.2-1.75(\mathrm{~m}, 4 \mathrm{H}$,

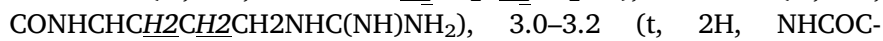
$\mathrm{HCH}_{2} \mathrm{CH}_{2} \mathrm{CH}_{2} \mathrm{CH}_{2} \mathrm{NH}$ ), 4.5-4.7 (1H, t, NHCHCH$\left.{ }_{2} \mathrm{COOH}\right), 8.0-8.25$ (m, $5 \mathrm{H}, \mathrm{N} \underline{H}$ backbone), 2.8-3.2 (d, $2 \mathrm{H}, \mathrm{NHCHC}_{2} \mathrm{COOH}$ ), 4.0-4.25 (d, $\left.2 \mathrm{H}, \mathrm{NHCOC} \underline{H}_{2} \mathrm{NH}\right), 4.25\left(1 \mathrm{H}, \mathrm{t}, \mathrm{NHCOC} \mathrm{HCH}_{2} \mathrm{C}_{6} \mathrm{H}_{5}\right), 2.9-3.3(2 \mathrm{H}, \mathrm{t}$, NHCOCHCH $\left.\mathrm{H}_{2} \mathrm{C}_{6} \mathrm{H}_{5}\right), \quad 7.0-7.5\left(5 \mathrm{H}, \mathrm{m}, \mathrm{CH}_{2} \mathrm{C}_{6} \underline{H}_{5}\right), 10.6(1 \mathrm{H}, \mathrm{s}$, $\left.\mathrm{NHCHCH}_{2} \mathrm{COO} \underline{H}\right)$.

\subsection{RAFT polymerization of OEG acrylate (OEGA) with cRGD RAFT agent} (4)

A typical polymerization procedure using cRGD modified RAFT agent is described as follows:

OEGA, cRGD modified RAFT agent and 2,2'-azobisisobutyronitrile (AIBN) as radical initiator were dissolved in $\mathrm{N}, \mathrm{N}$-dimethyl acetamide (DMAc). Briefly, OEG acrylate $(0.18 \mathrm{mmol})$, cRGD modified RAFT agent $(0.006 \mathrm{mmol})$ and AIBN $(0.0015 \mathrm{mmol})$ were mixed in DMAc $(0.9 \mathrm{ml})$ in a glass vial. Monomer: RAFT agent: initiator mol ratio was 30:1:0.25 with a fixed monomer concentration of $0.20 \mathrm{M}$. The mixture was degassed with nitrogen gas in an ice bath for $30 \mathrm{~min}$. The flask was then immersed in an oil bath at $65^{\circ} \mathrm{C}$. After $6 \mathrm{~h}$, the polymerization was terminated by placing the flask in an ice bath for 5 min and then exposing it to air. A portion of polymerization mixture was dried and analyzed by ${ }^{1} \mathrm{H}$ NMR spectroscopy to determine monomer conversion. Monomer conversions were determined by comparing the area of the vinyl protons $(\delta \sim 5.4-6.3 \mathrm{ppm}(3 \mathrm{H})$ ) to the area of the OEGA characteristic protons $(\delta \sim 4,3 \mathrm{ppm},(2 \mathrm{H})$ ).

The polymer was precipitated in $n$-hexane and centrifuged at $3000 \mathrm{rpm}$ for $5 \mathrm{~min}$, followed by two subsequent precipitations into $n$ hexane. The solvent was decanted and the polymer was dried in a vacuum oven for $2 \mathrm{~h}$. The number average molecular weight $\left(\mathrm{M}_{\mathrm{n}}\right)$ and molecular weight distribution (PDI) were determined by GPC using DMAc as the mobile phase.

\subsection{RAFT polymerization of t-butyl methacrylate with cRGD RAFT agent.}

A typical polymerization procedure using cRGD modified RAFT agent is described as follows: t-butyl methacrylate, cRGD modified RAFT agent and AIBN were dissolved in DMAc. Briefly, t-butyl methacrylate $(1 \mathrm{mmol})$, cRGD modified RAFT agent $(0.0125 \mathrm{mmol})$ and AIBN $(0.003 \mathrm{mmol})$ were mixed in DMAc $(1.0 \mathrm{ml})$ in a glass vial. The monomer: RAFT agent: initiator mol ratio was 80:1:0.25 at a monomer concentration of $1.0 \mathrm{M}$. The mixture was degassed with nitrogen gas in an ice bath for $30 \mathrm{~min}$. The flask was then immersed in an oil bath at $65^{\circ} \mathrm{C}$. The samples were taken at different time points, and polymerization was terminated by placing the flask in an ice bath for $5 \mathrm{~min}$ and then exposing it to air. A portion of polymerization mixture was dried and analyzed by ${ }^{1} \mathrm{H}$ NMR spectroscopy to determine monomer conversion. The polymer was precipitated in methanol/water mixture 


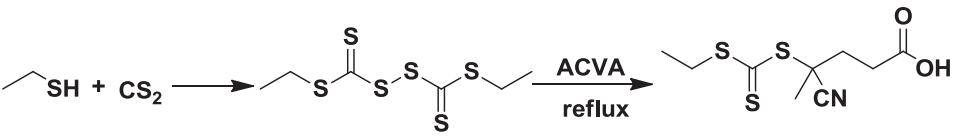

(1)<smiles>CCSC(=S)SC(C)(C)CCC(=O)ON1C(=O)CCC1=O</smiles>

(2)<smiles>N=C(N)NCCCC(NC(=O)CNC(=O)C(CC(=O)O)NC(=O)C(Cc1ccccc1)NC(=O)C(CCCCN)NC(=O)CNC(=N)N)C(=O)O</smiles>

Cyclic RGD<smiles>CCSC(=S)SC(C)(C)CCC(=O)NCCCCC(NC(=O)C(CCCNC(=N)N)NC(=O)CNC(=O)C(CC(=O)O)NC(=O)C(Cc1ccccc1)NC(=O)CSC(=O)O)C(=O)NC(C)(C)C</smiles>

(3)

(3)

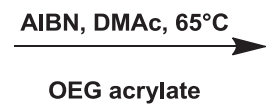<smiles>N=C(N)NCCCC(NC(=O)CNC(=O)C(CC(=O)O)NC(=O)CO)C(N)=O</smiles>

(3)

AIBN, DMAc, $65^{\circ} \mathrm{C}$

t-BMA

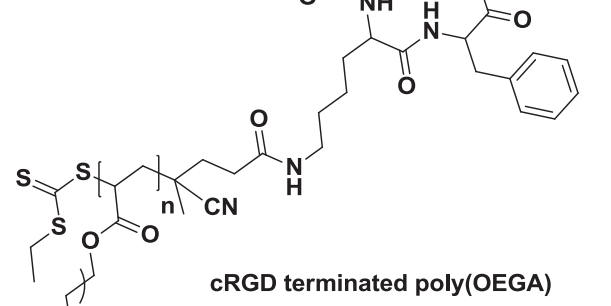

(4)<smiles>COC(C)(CO)CO</smiles><smiles>N=C(N)NCCCC(NC(=O)CNC(=O)C(CC(=O)O)NC(=O)CN)C(N)=O</smiles><smiles>CCSC(=S)SC(C)(CC(C)(C)CCC(=O)NCCCCC(NC(C)=O)C(=O)NC(Cc1ccccc1)C(=O)NC)C(=O)OC(C)(C)C</smiles>

(5)

Scheme 1. Synthesis of 4-cyano-4-(ethylsulfanylthiocarbonyl) sulfanyl pentanoic acid (1), 4-cyano-4-ethylsulfanylthiocarbonylsulfanyl-4-methyl-butyric acid 2,5dioxo-pyrrolidin-1-yl ester (2), cRGD modified RAFT agent (3), cRGD terminated poly(OEGA) (4), cRGD terminated poly (t-BMA) (5).

and centrifuged at $3000 \mathrm{rpm}$ for $5 \mathrm{~min}$ followed by two subsequent precipitations into methanol/water mixture. The solvent was decanted and the polymer was dried in a vacuum oven for $2 \mathrm{~h} . \mathrm{M}_{\mathrm{n}}$ and PDI were determined by GPC using DMAc as the mobile phase.
2.5. Chain-extension polymerization of poly(OEGA) macroRAFT agent with OEGA.

The livingness of OEGA polymers synthesized by cRGD RAFT agent was shown by chain extension polymerization of poly(OEGA) macroRAFT agent with OEG acrylate monomer. Synthesis of block 
copolymer was carried out using the following procedure:

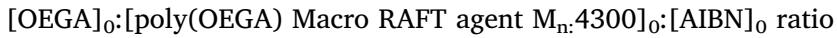
of 30:1:0.25 was used. Briefly, OEGA $(175 \mathrm{mg}, 0.365 \mathrm{mmol})$, poly (OEGA) macro RAFT agent $\mathrm{M}_{\mathrm{n}:} 4300$ (52 mg, $0.0121 \mathrm{mmol}$ ), AIBN $(0.5 \mathrm{mg}, 0.0030 \mathrm{mmol})$ and DMAc $(1.4 \mathrm{ml})$ were placed in a glass vial equipped with a magnetic stirrer bar and capped with a rubber septum. The reaction mixture was deoxygenated for $25 \mathrm{~min}$ at $0{ }^{\circ} \mathrm{C}$ by purging with $\mathrm{N}_{2}$. The deoxygenated and sealed reaction vessel was placed into a pre-heated oil bath at $65^{\circ} \mathrm{C}$ and the samples were taken at different time points. The resulting mixture was then allowed to cool to $0{ }^{\circ} \mathrm{C}$ for about $15 \mathrm{~min}$ and exposed to air to terminate polymerization. The monomer conversion was determined by ${ }^{1} \mathrm{H}$ NMR. The polymer was purified by first precipitating into $n$-hexane, followed by two subsequent precipitations into $n$-hexane. The product was then placed in a vacuum oven for $2 \mathrm{~h}$. The final product was analyzed by ${ }^{1} \mathrm{H}$ NMR and GPC. Mn and PDI were determined by GPC using DMAc as the mobile phase.

\subsection{Determination of in vitro cytotoxicity of cRGD terminated poly(OEGA)}

Prior to the cytotoxic assays, the thiocarbonylthio RAFT end-group of cRGD-terminated poly(OEGA) was removed in order to avoid possible cytotoxicity of this active group [50]. To remove the RAFT end group, protocols well known in literature have been performed [51,52]. Briefly cRGD-terminated poly(OEGA) $\left(\mathrm{M}_{\mathrm{n}} 6700 \mathrm{~g} / \mathrm{mol}\right.$, PDI:1.2, $0.0029 \mathrm{mmol}$ ) dissolved in methanol was reacted with hexylamine $(0.118 \mathrm{mmol})$ and triethylamine $(0.118 \mathrm{mmol})$ in the presence of OEGA monomer $(0.0089 \mathrm{mmol})$. The mixture was stirred for $16 \mathrm{~h}$. The reaction completion was monitored by a UV-Vis spectrophotometer by scanning the absorbance in the range between $200 \mathrm{~nm}$ and $800 \mathrm{~nm}$. After reaction time, methanol was removed by vacuum evaporation. The polymer was then precipitated in cold $n$-hexane ( 2 times) and dried under vacuum. The polymer was further purified by dialysis against water using a dialysis tubing with a molecular weight cutoff of $3000 \mathrm{Da}$ for four days. The resultant polymer was then dried using a freeze-drier. For the comparison, poly(OEGA) synthesized using ECT RAFT agent without cRGD modification $\left(\mathrm{M}_{\mathrm{n}} 6200 \mathrm{~g} / \mathrm{mol}\right.$, PDI: 1.24$)$ was also aminolyzed using the same above procedure. The effect of both polymers on the viability of BEAS-2B (human bronchial epithelium) and A549 (human lung adenocarcinoma epithelial) cells was determined by a 3(4,5-dimethylthiazol-2-yl)-2,5-diphenyl tetrazolium bromide (MTT) Cell Viability assay [53]. The assay measures the ability of living cells to reduce a tetrazolium dye, MTT to its insoluble formazan giving a purple color.

In cell viability experiments, BEAS-2B (human bronchial epithelium) and A549 (human lung adenocarcinoma epithelial) cell lines with passage number 3-10 were seeded a day prior to sample exposure at $10^{4}$ cells/well (96 well-plate) in DMEM culture medium containing $10 \%$ FBS. Polymer sample stocks (cRGD terminated polymer and the polymer without CRGD) were prepared by dissolving in PBS at predetermined concentrations. $5 \mu \mathrm{l}$ of polymer stocks in PBS were added to the wells in triplicate. $5 \mu \mathrm{l}$ of only PBS was also added into wells for positive control experiments. The cells were incubated at $37^{\circ} \mathrm{C}, 5 \% \mathrm{CO}_{2}$ for 24 or $72 \mathrm{~h}$. Following the incubation, the viability of the cell was determined by MTT Cell Viability assay. MTT dye was added to wells according to manufacturer's protocol. The plates were incubated at $37^{\circ} \mathrm{C}$ for $3 \mathrm{~h}$ in the dark atmosphere. After the incubation the well plates were centrifuged at $1800 \mathrm{rpm}$ for $10 \mathrm{~min}$. Supernatants were removed by pouring and the crystals were dissolved in DMSO $(100 \mu \mathrm{l})$. Metabolic activity was detected by measuring the absorbance at $570 \mathrm{~nm}$ using a microplate spectrophotometer (Varioskan Flash, Thermo Electron Corporation, Finland). The cell viability (\%) was calculated relative to the positive control (cells not treated with polymers) according to Eq. (1)
Cell viability $(\%)=\frac{A_{\text {cell sample }}-A_{\text {blank }}}{A_{\text {positive control }}-A_{\text {blank }}} \times 100$

\subsection{Cell uptake by flow cytometry}

Uptake of cRGD-terminated poly(OEGA) $\left(\mathrm{M}_{\mathrm{n}}: 6700 \mathrm{~g} / \mathrm{mol}\right.$, PDI: 1.2) and poly(OEGA) without $\mathrm{cRGD}\left(\mathrm{M}_{\mathrm{n}}: 6200 \mathrm{~g} / \mathrm{mol}\right.$, PDI: 1.2) by BEAS-2B (human bronchial epithelium) and A549 (human lung adenocarcinoma epithelial) cells was investigated using a flow cytometry (BD FACSCantoTM A Flow Cytometer, BD Biosciences, San Jose, USA).

Prior to the cell uptake experiment, cRGD-terminated polymer and poly(OEGA) without cRGD were labeled with Oregon Green maleimide 488 according to manufacturer's protocol. Firstly, Oregon Green maleimide $488\left(5 \mathrm{mg}, 1.08 \times 10^{-5} \mathrm{~mol}\right)$ was dissolved in DMF $(108 \mu \mathrm{l})$ to have a stock dye solution of $100 \mathrm{mM}$. The dye solution $(24.5 \mu \mathrm{l}$, $0,25 \times 10^{-5} \mathrm{~mol}$ ) was added to thiol and cRGD-terminated polymer solution after aminolysis (Mn: $6700 \mathrm{~g} / \mathrm{mol}$, PDI:1.2) in phosphate buffer $\left(0.1 \mathrm{M}, \quad 500 \mu \mathrm{l}, \quad 0.05 \times 10^{-5} \mathrm{~mol}\right)$. TCEP $\quad(0.02 \mathrm{M}, \quad 2.8 \mathrm{mg}$, $1 \times 10^{-5} \mathrm{~mol}$ ) dissolved in phosphate buffer solution at $\mathrm{pH} 7.1$ was also added to the reaction mixture. The reaction solution was purged with nitrogen for $10 \mathrm{~min}$ and gently shaken overnight at $37^{\circ} \mathrm{C}$. The product was then dialyzed against water using a membrane with a MW cutoff of $3500 \mathrm{Da}$ for 4 days and finally freeze-dried. The degree of labelling was determined via UV-Vis spectroscopy (Perkin Elmer Lambda $25 \mathrm{UV} / \mathrm{Vis}$ Spectrometer).

As a control, poly(OEGA) without cRGD functionalization was also labelled with Oregon Green maleimide 488 using the same procedure for comparison.

BEAS-2B and A549 cells $\left(10^{5}\right.$ cells $/ 500 \mu$ per well) were seeded in 24 well-plates and incubated in a humidified atmosphere $\left(37^{\circ} \mathrm{C}, 5 \%\right.$ $\mathrm{CO}_{2}$ ) for $24 \mathrm{~h}$. After $24 \mathrm{~h}$, Oregon Green labelled polymers with and without cRGD (dissolved in PBS) were added into wells $(30 \mu \mathrm{l})$ to yield a final polymer concentration of $20 \mu \mathrm{M}$. The cells and polymers were incubated for $30 \mathrm{~min}$ or $60 \mathrm{~min}$ at $37^{\circ} \mathrm{C}$. Each treatment was performed in triplicate. At the end of incubation, medium was collected and the wells were washed with cold PBS. The cells were harvested by trypsinization and collected cells were centrifuged for $5 \mathrm{~min}$. Supernatant was removed and pellet was resuspended with $200 \mu \mathrm{PBS}$ and transferred to flow cytometry tubes for analysis. Data from 10,000 events were collected per sample via flow cytometry and analysed by using FacsDiva V.5.0.3 software. Solid state 488 laser was used for excitation and 530/ 30 filter configuration for detection of Oregon Green. The experiments were performed in triplicate. Each experiment was repeated twice. Mean values and standard deviations $(n=6)$ were determined and presented in the corresponding results/graph. Statistical analysis ( $t$-test) was performed to evaluate the significance of the differences in results $(* * \mathrm{P}<0.01, * * * \mathrm{P}<0.001)$.

\section{Results and discussions}

To in-situ synthesize cRGD-end-functionalized well-defined polymers via RAFT polymerization, a new RAFT agent containing cRGD peptide was first synthesized (Scheme 1). Considering the basic character of cRGD peptide, 4-cyano-4-(ethylthiocarbonothioylthio) pentanoic acid (ECT) was selected as a suitable chain transfer agent (CTA) as it is relatively more resistant to hydrolysis and aminolysis. This RAFT agent is basically different than the other bulk RAFT agents which have large Z-groups such as dodecyl and phenyl. The presence of alkyl group at Z-group of the RAFT agent controls the hydrolysis and aminolysis during modification with cRGD peptide. Consequently, ECT RAFT agent was successfully synthesized according to method given by Moad et al. [49] (Fig. S1) (Supporting Information, SI).

Synthesis of cRGD modified RAFT agent involves a two-step process. The first step is the activation of carboxylic acid of ECT RAFT agent using DCC/NHS chemistry [54]. The direct conversion of a carboxylic 


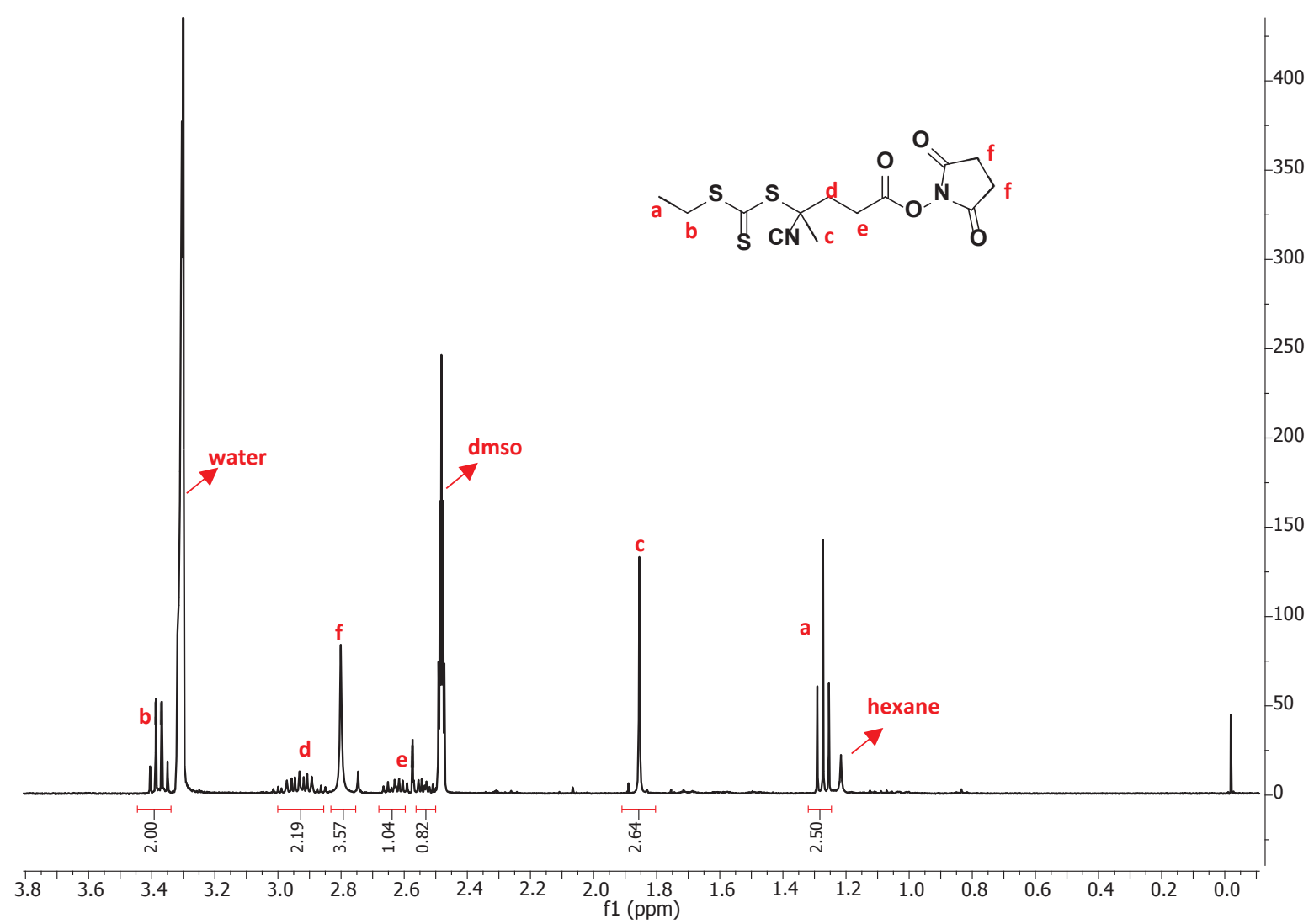

Fig. 1. ${ }^{1}$ HNMR spectrum of 4-cyano-4-ethylsulfanylthiocarbonylsulfanyl-4-methyl-butyric acid 2,5-dioxo-pyrrolidin-1-yl ester (NHS ester of ECT RAFT agent) (in DMSO- $d_{6}$ ) after purification.

acid functional RAFT agent to a cRGD modified RAFT agent is difficult because cRGD contains basic amine group which converts carboxylic acids to their highly unreactive carboxylates. In DCC/NHS reaction, the carboxylic acid present in the RAFT agent adds to the DCC molecule to form o-acylisourea intermediate. Irreversible rearrangement of the desired, activated intermediate o-acylisourea to the non-reactive $\mathrm{N}$-acylurea is suppressed by reacting o-acylisourea intermediate with NHS molecule to form an active ester which is a good leaving group. The active ester can then be displaced by cRGD amine during nucleophilic substitution. After active ester formation, the dicyclohexylurea (DCU) by-product was filtered off and slurried by diethyl ether. The product was then characterized using ${ }^{1}$ HNMR spectroscopy as shown in Fig. 1. The appearance of a broad peak at $2.8 \mathrm{ppm}$ corresponds to NHS moiety [56] indicating the formation of a 4-cyano-4-ethylsulfanylthiocarbonylsulfanyl-4-methyl-butyric acid 2,5-dioxo-pyrrolidin-1-yl ester (active ester).

The second step involves the reaction of NHS ester of ECT RAFT agent with the lysine amine group of cRGD peptide. The product (theoretical mass: 848.6 g/mol) was characterized using ${ }^{1} \mathrm{H}$ NMR and mass spectroscopies. The major peak in the mass spectrum (Fig. 2) at an $\mathrm{m} / \mathrm{z}$ ratio of 849.80 revealed the covalent conjugation of the cRGD peptide to the RAFT agent via the primary amine side chain group of the cRGD peptide and acid group of RAFT agent's "R" group. The presence of characteristic peaks of cRGD and RAFT agent in the NMR spectrum shown in Fig. 3 indicated the successful conjugation of cRGD peptide with the RAFT agent.

Trithiocarbonate RAFT agents are known to have reasonable control over polymerizations of both acrylates and methacrylates. Therefore two different monomers, an acrylate and methacrylate, which are both relevant to biological applications have been chosen as model monomers to show the ability of the new RAFT agent to control polymerizations of both mono- and di-substituted olefinic monomers. The acrylate-based monomer OEGA was selected since OEGA polymers have been commonly used in different biotechnological applications [55,56]. Similarly, a methacrylate monomer, t-BMA was also used as the polymers of t-BMA can be converted via acid-catalyzed hydrolysis to methacrylic acid polymers which are commonly used in biomedical applications such as drug delivery [46,57].

Oligoethylene glycol acrylate (OEGA) monomer was first polymerized using cRGD modified RAFT agent. The kinetics of RAFT polymerization was investigated by varying polymerization time at a monomer: RAFT: initiator mol ratio of 30:1:0.25 and a monomer concentration of $0.20 \mathrm{M}$. Similar experiments were also performed for RAFT polymerization of t-butyl methacrylate (t-BMA) at a monomer: RAFT: initiator ratio of 80:1:0.25 and a monomer concentration of 1.0 M. The results are shown in Table S1 and Fig. S2 (SI), and Fig. 4a and $\mathrm{b}$.

As the monomer conversion increases, the number average molecular weight $\left(\mathrm{M}_{\mathrm{n}}\right)$ of the polymers increases linearly (Fig. 4b). Similarly, $\ln \left(\left[\mathrm{M}_{0}\right] /[\mathrm{M}]\right)$ (first order) versus time plot showed a linear relation (Fig. 4a), which indicates well the RAFT-controlled polymerization mechanism of OEGA monomer [58,59]. Relatively narrow molecular weight distribution (PDI $\leq 1.26$ up to $60 \%$ monomer conversion) of poly(OEGA)s against calculated conversion values were also obtained (Fig. 4b). The kinetics results were similar with t-BMA polymerizations (Fig. 4a and b). Slightly higher PDI values (PDI $\leq 1.35$ up to $81 \%$ monomer conversion) obtained in the case of t-BMA polymerizations, can be explained on the basis of increase in steric hindrance making it difficult for the bulky tertiary propagating radical generated from tBMA to add to the $\mathrm{C}=\mathrm{S}$ of the RAFT agent [60]. The apparent propagation rate constant $\left(\mathrm{k}_{\mathrm{app}}\right)$ of polymerizations was $0.018 \mathrm{~h}^{-1}$ and $0.061 \mathrm{~h}^{-1}$ for OEGA and t-BMA, respectively, indicating faster polymerization reaction of t-BMA when compared with OEGA under the polymerization conditions used. In accordance with this finding, the ln 


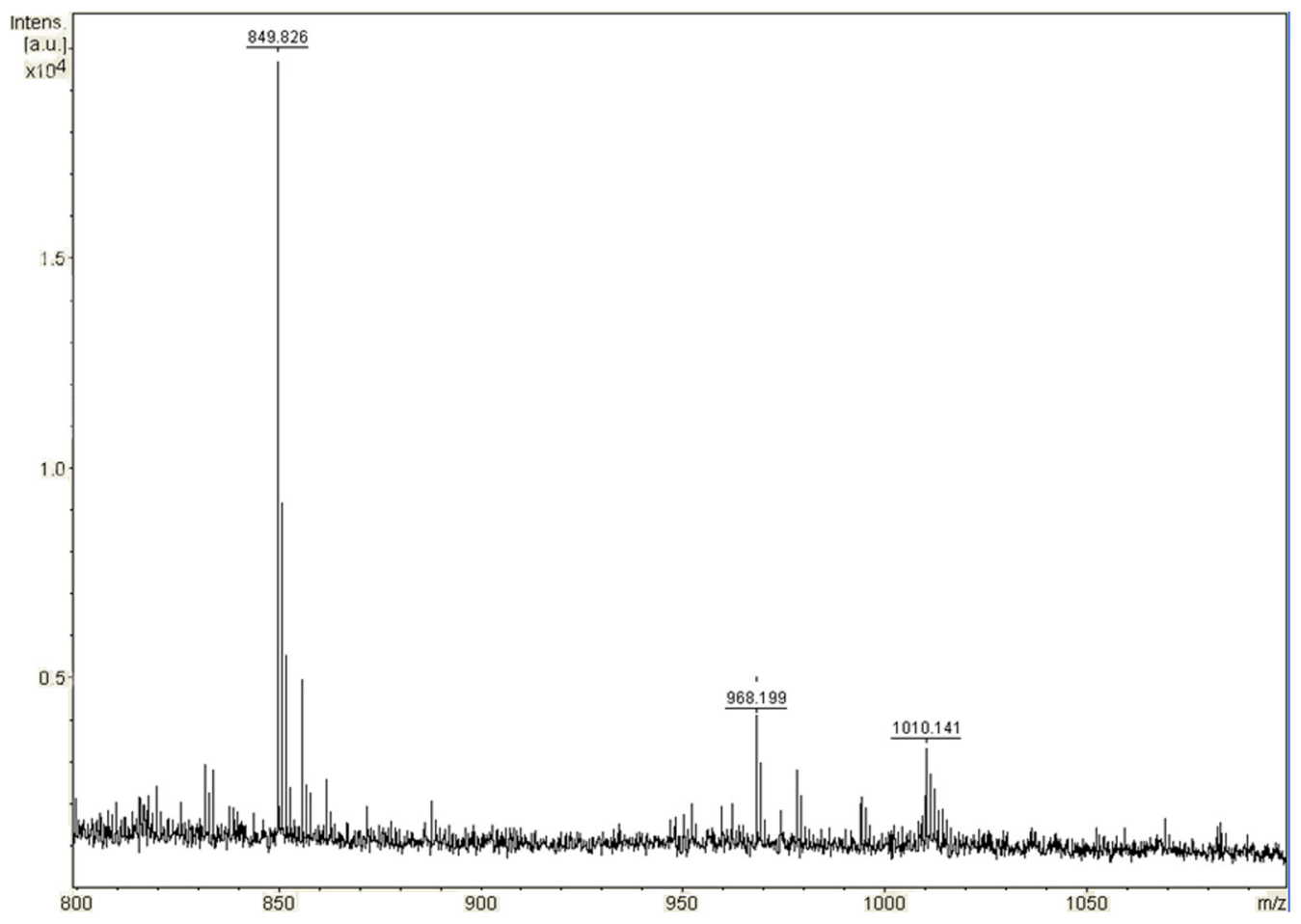

Fig. 2. Mass spectrum of cRGD modified 4-cyano-4-(ethylsulfanylthiocarbonyl) sulfanyl pentanoic acid (cRGD RAFT agent).

$\left(\left[\mathrm{M}_{0}\right] /[\mathrm{M}]\right)$ vs. time plot of t-BMA does not intersect with the origin, which might be due to the slower fragmentation rate of the RAFT agent with respect to the polymerization rate of t-BMA.

Representative ${ }^{1} \mathrm{H}$ NMR spectra of purified cRGD terminated poly
(OEGA) (conversion: 53\%, $\mathrm{M}_{\mathrm{n}}$, GPC: $6700 \mathrm{~g} / \mathrm{mol}$, PDI: 1.21 ) and cRGD terminated poly (t-BMA) (conversion: $66 \%, \mathrm{M}_{\mathrm{n}}$, GPC: $7750 \mathrm{~g} / \mathrm{mol}$, PDI: 1.24) are given in Fig. 5a and b. The spectra show all the signals expected for the polymer structures, and the signal at $7.1-7.3 \mathrm{ppm}$

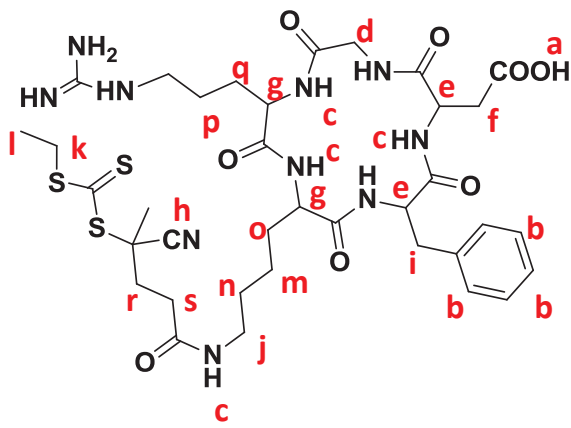

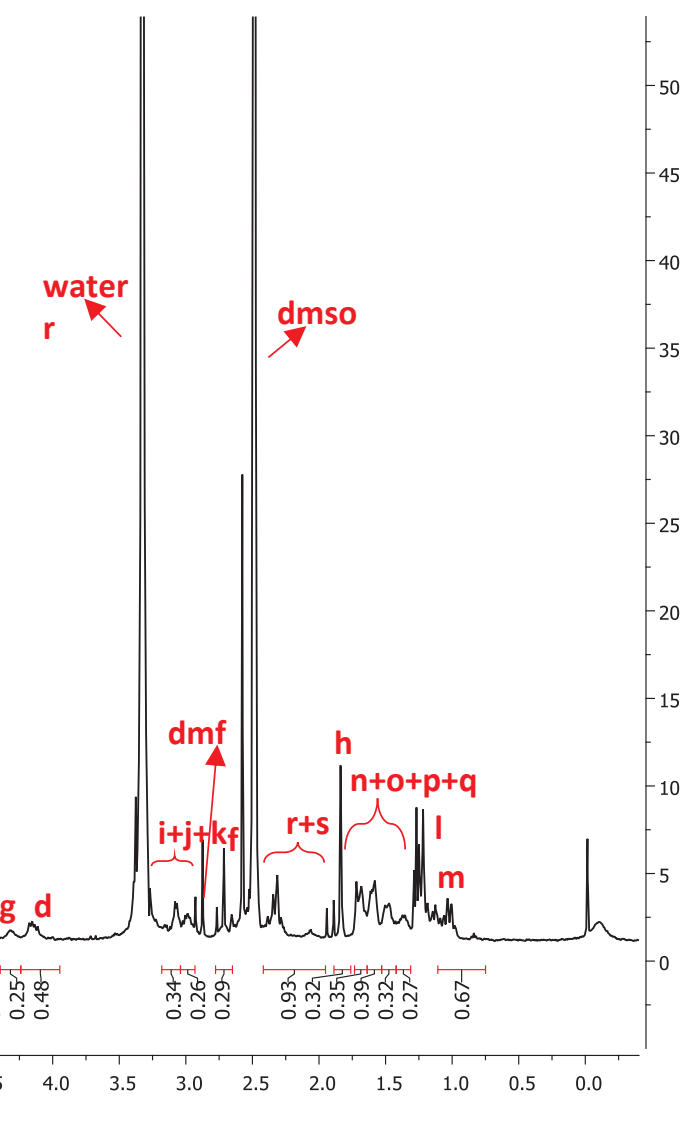

Fig. 3. ${ }^{1} \mathrm{H}$ NMR spectrum of cRGD RAFT agent in DMSO- $d_{6}$. 

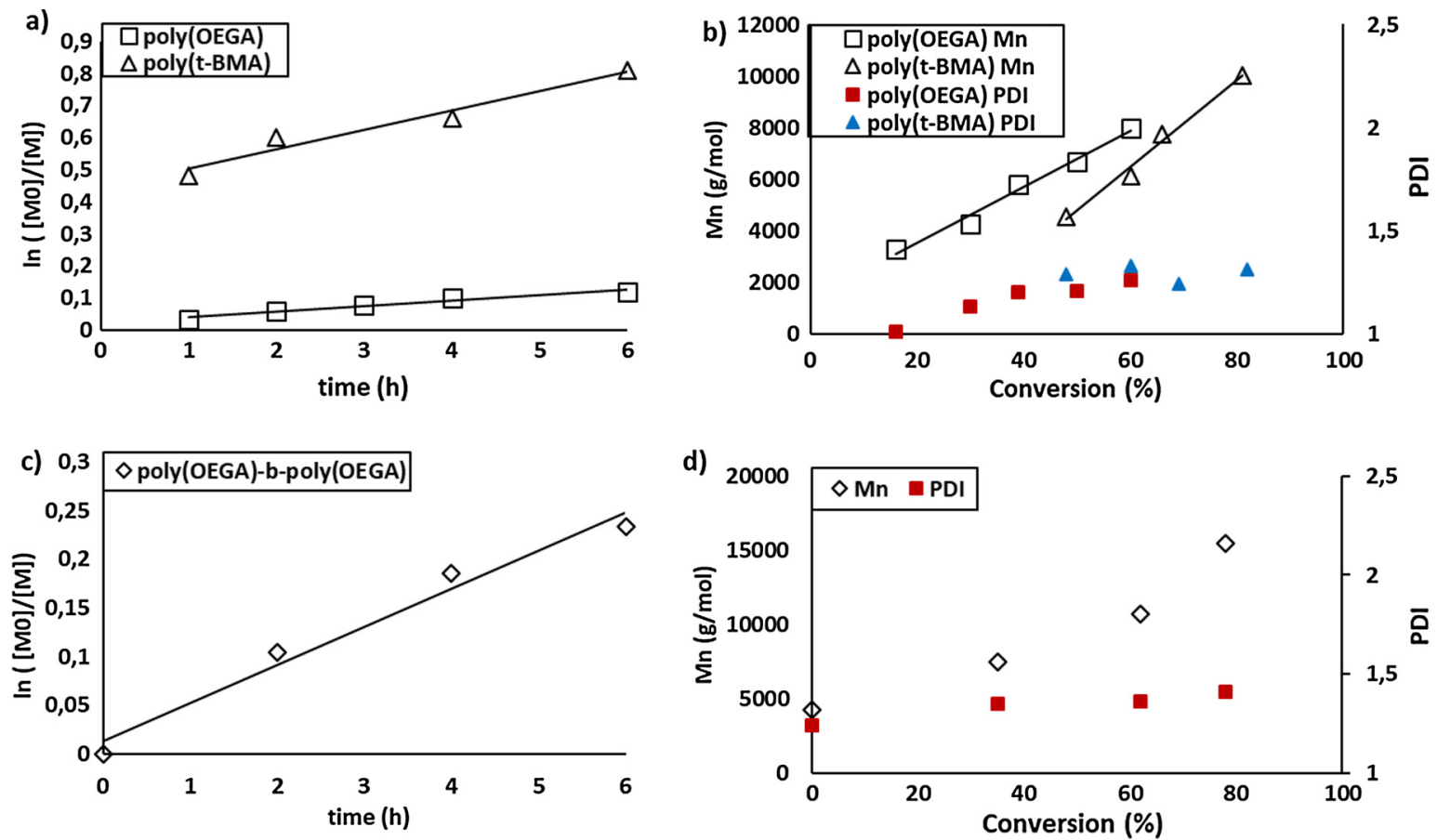

Fig. 4. (a) $\ln \left(\left[\mathrm{M}_{0}\right] /[\mathrm{M}]\right)$ versus polymerization time graph, and (b) $\mathrm{M}_{\mathrm{n}}$ (GPC) and PDI (GPC) versus conversion (by NMR) graph for homopolymerizations of OEGA and t-BMA using cRGD modified RAFT agent, in which monomer: RAFT agent: initiator mol ratio ([M]/[R]/[I]) was 30/1/0.25 and 80/1/0.25, respectively. (c) ln $\left(\left[\mathrm{M}_{0}\right] /[\mathrm{M}]\right)$ versus polymerization time graph, and (d) $\mathrm{M}_{\mathrm{n}}$ (GPC) and PDI versus conversion (NMR) graph for chain extension of poly(OEGA) macroRAFT agent with OEGA monomer ([OEGA $]_{0}:\left[\text { poly(OEGA) Macro RAFT agent } \mathrm{M}_{\mathrm{n}:}: 4300\right]_{0}:[\mathrm{AIBN}]_{0}$ was 30/1/0.25).

corresponding to the aromatic group [32] of cRGD proving the successful synthesis of cRGD functionalized polymers.

The living nature of cRGD-ended polymers was further verified by chain extension of poly(OEGA) $\left(\mathrm{M}_{\mathrm{n}}: 4300 \mathrm{~g} / \mathrm{mol}\right.$ and PDI: 1.13 by GPC) with OEGA monomer using a [OEGA $]_{0}:[$ poly(OEGA) Macro RAFT Agent $]_{0}:[\mathrm{AIBN}]_{0}$ mol ratio of 30:1:0.25 at a monomer concentration of $0.26 \mathrm{M}$. The polymerization results are shown in Table S2 (SI). In $\left(\left[\mathrm{M}_{0}\right] /[\mathrm{M}]\right)$ (first order) versus time plot showed a linear relation (Fig. 4c). Also, as the monomer conversion increases, $M_{n}$ of the polymers increases linearly (Fig. 4d). $\mathrm{k}_{\mathrm{app}}$ for chain extension polymerization was found to be $0.039 \mathrm{~h}^{-1}$. Since the initial monomer and initiator concentrations were higher in chain extension polymerizations when compared with homopolymerization, a higher $\mathrm{k}_{\mathrm{app}}$ value is expected. All these indicate well the RAFT-controlled chain extension polymerization mechanism $[58,59]$. Fig. $4 \mathrm{~d}$ shows narrow molecular weight distribution of the block copolymers against calculated conversion values. The increase in PDI $(\sim 1.13$ to 1.41$)$ is expected due to the polydispersity of macroRAFT agent and termination reactions at higher monomer conversions. These results show that the polymer chains synthesized using new cRGD-functional RAFT agent had a living character and the ability to control over copolymerization.

Before performing the cytotoxicity assays, the trithiocarbonate RAFT end group of cRGD terminated poly(OEGA) was removed as this reactive group might possess toxic effects on living cells [50]. The RAFT end-group was cleaved in the presence of hexylamine, triethylamine and OEGA monomer, following a procedure reported previously in the literature [51,52]. The UV-Vis spectra after aminolysis are shown in Fig. S3 (SI), which revealed that the living trithiocarbonate end-group was effectively removed.

The cRGD terminated poly(OEGA) $\left(\mathrm{M}_{\mathrm{n}}: 6700 \mathrm{~g} / \mathrm{mol}\right)$ and a control polymer, poly(OEGA) without cRGD end-group $\left(\mathrm{M}_{\mathrm{n}}: 6200 \mathrm{~g} / \mathrm{mol}\right)$ at varying concentrations $(20 \mu \mathrm{M}, 10 \mu \mathrm{M}, 5 \mu \mathrm{M}, 2.5 \mu \mathrm{M}$ and $1.25 \mu \mathrm{M})$ were incubated with A549 (human lung adenocarcinoma epithelial) or BEAS2B (human bronchial epithelium) cells for 24 and $72 \mathrm{~h}$. The viability of A549 and BEAS-2B cells after incubation with the polymers (for $24 \mathrm{~h}$ and $72 \mathrm{~h}$ ) was determined via MTT assay. The results shown in Fig. 6a and $\mathrm{b}$ indicated that cRGD terminated polymer and its counterpart without cRGD did not have any cytotoxic effect on A549 and BEAS cells at all concentrations after incubation for $24 \mathrm{~h}$ or $72 \mathrm{~h}$. The cell viability was higher than $85 \%$ at all conditions tested. This result showed that the conjugation of cRGD peptide to the OEGA polymer did not alter the nontoxic nature of the OEGA polymer.

To investigate the targeted uptake of cRGD-functionalized poly (OEGA) by cells, cRGD-functionalized poly(OEGA) and its counterpart polymer without cRGD end-group were labelled with Oregon Green ${ }^{\circledR}$ 488 Maleimide. Before performing labelling, the trithiocarbonate RAFT end group of cRGD-terminated poly (OEGA) $\left(\mathrm{M}_{\mathrm{n}}: 6700 \mathrm{~g} / \mathrm{mol}\right)$ and its counterpart polymer without cRGD end-group $\left(\mathrm{M}_{\mathrm{n}}: 6200 \mathrm{~g} / \mathrm{mol}\right)$ were aminolyzed and conjugated with Oregon Green ${ }^{\circledR} 488$ Maleimide in the presence of TCEP and phosphate buffer.

The fluorophore number per polymer chain ( $\mathrm{mol}$ of $\mathrm{OG} / \mathrm{mol}$ of polymer) was determined using UV-Vis spectroscopy at $491 \mathrm{~nm}$ (the extinction coefficient of $O G$ at $491 \mathrm{~nm}: 81000 \mathrm{M}^{-1} \mathrm{~cm}^{-1}$ ) (Fig. 7). Based on the absorbance values of polymer solutions at $491 \mathrm{~nm}$, the extinction coefficient of the dye, and the polymer molar concentrations used in the measurements, the degree of labelling was calculated according to Beer-Lambert Law (Fig. 7 and Table S3 (SI)) giving in Eq. (2) considering all the dilutions made during measurements:

$\mathrm{Abs}_{\text {labelled polymers }}=\varepsilon \times$ concentration of dye $\times$ path length

where Abs is the absorbance of the polymer solution at $491 \mathrm{~nm}, \varepsilon$ is the extinction coefficient of the dye at $491 \mathrm{~nm}\left(81,000 \mathrm{M}^{-1} \mathrm{~cm}^{-1}\right.$ according to the manufacturer).

The cell uptake of OG-labelled polymers $(20 \mu \mathrm{M})$ after incubation with A549 and BEAS cells for $30 \mathrm{~min}$ or $60 \mathrm{~min}$ was investigated using flow cytometry that enabled quantitative analysis of fluorescence-associated cells. The flow cytometry plots and $\%$ of cell uptake results were shown in Fig. 8a and b. The \% cell uptake was determined after normalizing the flow cytometry data considering the labeling degree of polymers. 
a)
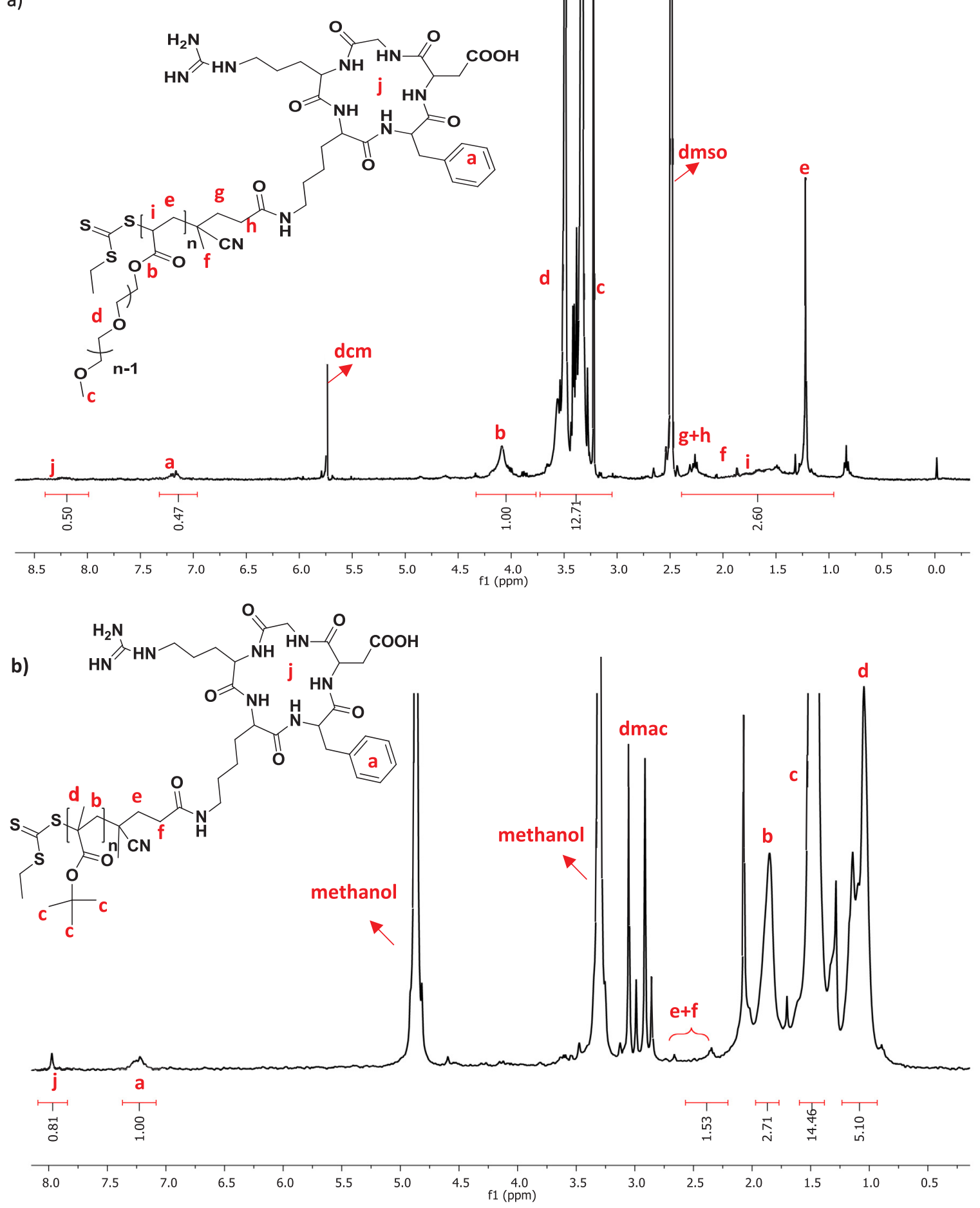

Fig. 5. ${ }^{1} \mathrm{H}$ NMR spectra of purified cRGD terminated (a) poly(OEGA) (conversion: $53 \%, \mathrm{M}_{\mathrm{n}, \mathrm{GPC}}: 6700 \mathrm{~g} / \mathrm{mol}$, PDI: 1.21 ) in DMSO- $d_{6}$ and (b) poly(t-BMA) (conversion $=66 \%, M_{n, G P C}: 7750 \mathrm{~g} / \mathrm{mol}$, PDI: 1.24$)$ in methanol- $d_{4}$.

It has been reported in the literature that the peptides and proteins containing RGD motifs, either in linear or cyclic form, recognize $\alpha_{v} \beta_{3}$ integrins and that this recognition can be used to target drugs to tumor cells [61]. Different cell lines express varying integrin proteins at different extents while cancer cells usually overexpress them [62-65]. Lung cancer cells are among the cancer cells overexpressing $\alpha_{v} \beta_{3}$ integrin receptors $[62,65]$. Accordingly, we have utilized A549 (human lung adenocarcinoma epithelial) cell line as a model cell line overexpressing RGD-binding integrin receptors along with human bronchial epithelium BEAS-2B cells [63-65]. The uptake of cRGD terminated poly (OEGA) by A549 and BEAS-2B cells was investigated and compared to its non-RGD counterpart. For both polymers, time-dependent increase 
poly(OEGA) with cRGD end-group
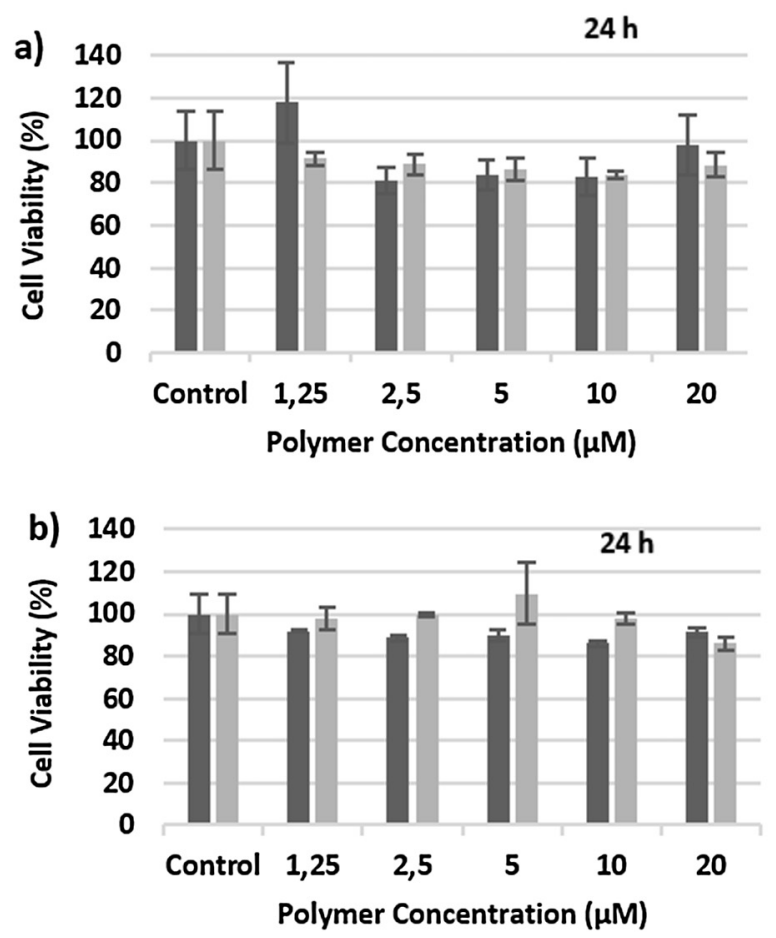

poly(OEGA) without cRGD end-group
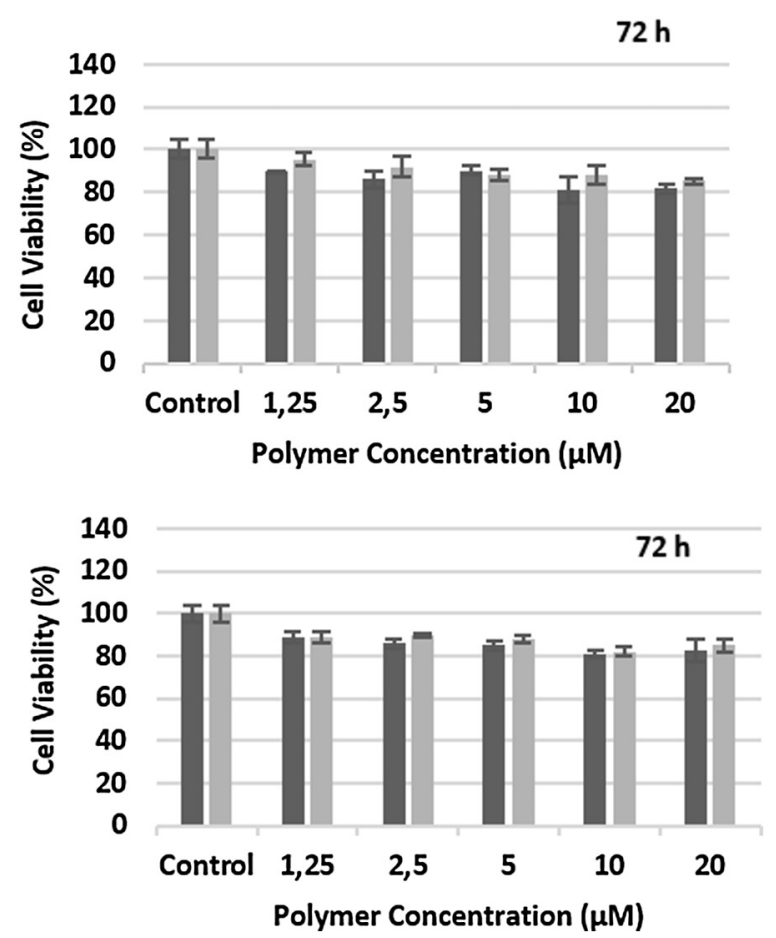

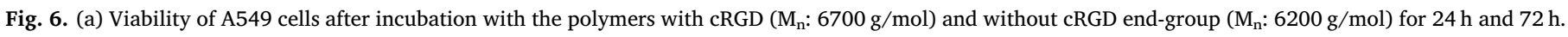

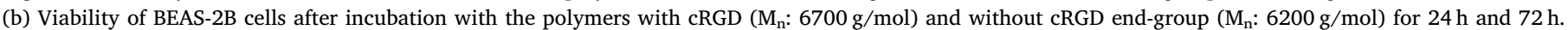
Control is the cells with no treatment.

in uptake was observed (Fig. 8). According to the statistically analyzed data ( $t$-test, $\mathrm{n}=6,{ }^{* *} \mathrm{P}<0.01,{ }^{* * *} \mathrm{P}<0.001$ ), the percentage cell uptake of cRGD terminated poly(OEGA) was significantly higher for both cell lines and incubation periods compared to poly(OEGA) without cRGD end-group.

Compared to the non-cRGD counterpart, the cRGD modified polymer was taken up by A549 cells between 1.5 and 2.1-fold excess at two different time points tested, indicating that the RGD motif has the ability to recognize targeted integrin $\alpha_{\mathrm{v}} \beta_{3}$ receptors overexpressed on the cancer cells. Indeed, after $30 \mathrm{~min}$ and $60 \mathrm{~min}$ incubations, the percentage of A549 cancer cells taking up cRGD terminated OEGA polymer was around $22.5 \%$ and $49.6 \%$ while the uptake of non-cRGD polymer by the same cells was $10.6 \%$ and $33.6 \%$, respectively. The difference between the uptake of cRGD-terminated and non-cRGD polymer by
A549 cells was found to be significantly different according to the statistical analysis. On the other hand, BEAS-2B cells took up cRGD modified polymer between 4.6 - and 2.2 -fold excess at $30 \mathrm{~min}$ and 60 min incubations when compared with the non-cRGD polymer uptake, also suggesting the role of integrin receptors in the uptake cRGD modified polymer by BEAS-2B cells. However, the total polymer uptake of BEAS-2B cells was significantly less than that of A549 cells, attributed to the increased metabolic activity of cancer cells. In accordance with the higher metabolic activity of A549 cells, the cRGD-terminated and non-cRGD poly(OEGA) showed approximately 2.6- and 4.7-fold higher uptake, respectively, in A549 cancer cells as compared to BEAS2B cells. Nevertheless, all the results suggest that the cRGD terminated polymer, when compared with the non-cRGD counterpart, show higher and accelerated cellular uptake in lung cancer cells and bronchial

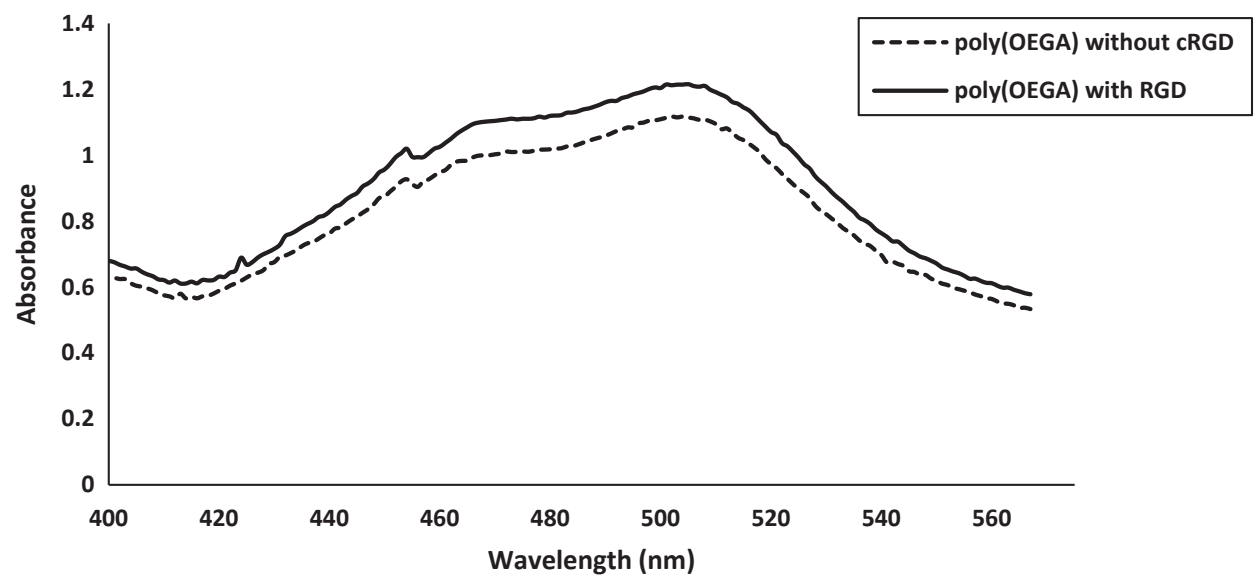

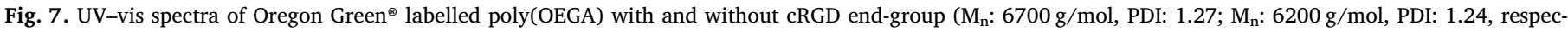
tively). The concentration of both polymers was $45 \mu \mathrm{M}$ during UV-Vis spectroscopy measurement. 
a)

A549

30 min incubation

A549

60 min incubation

BEAS-2B

$30 \mathrm{~min}$ incubation

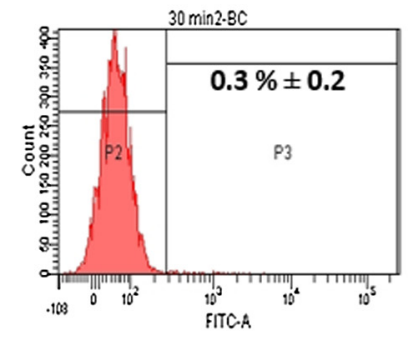

BEAS-2B

$60 \mathrm{~min}$ incubation

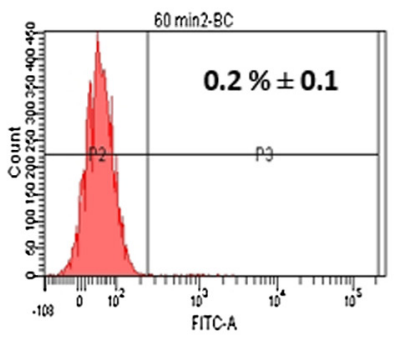

POLY(OEGA) W/O cRGD
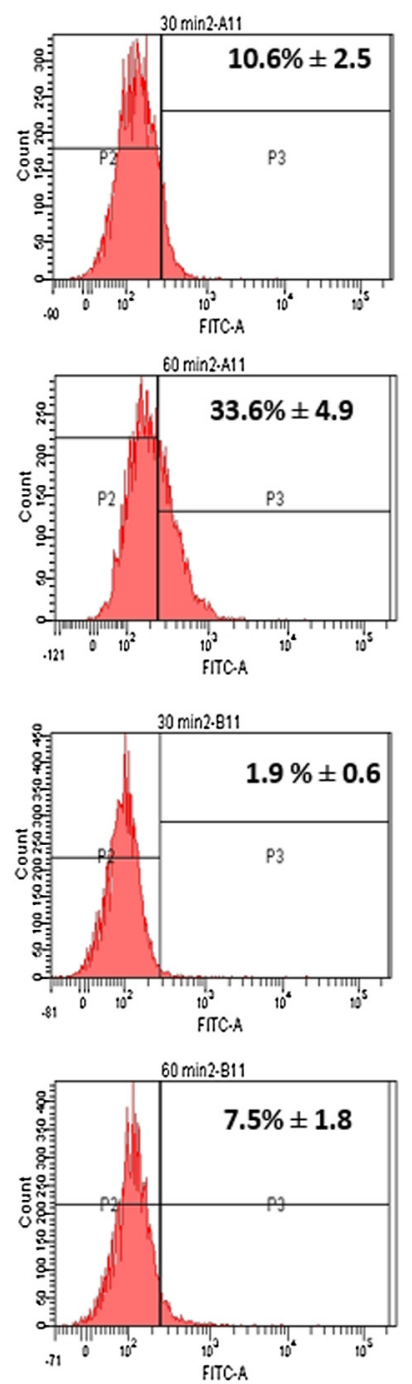

POLY(OEGA) W/ CRGD
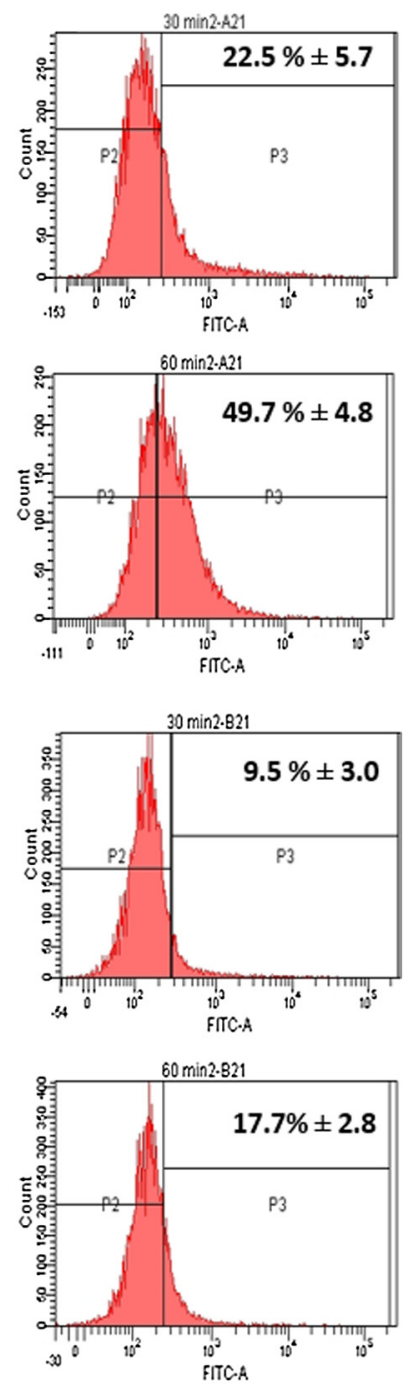

b)

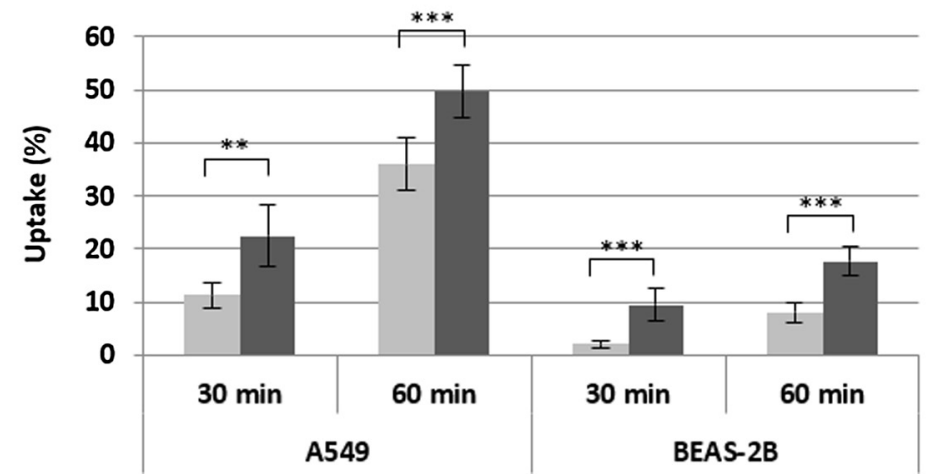

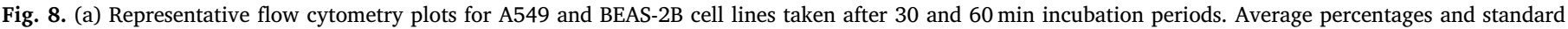

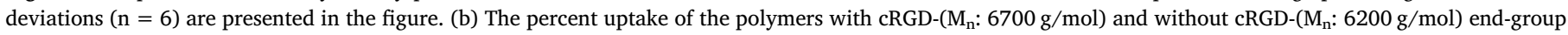
by A549 and BEAS-2B cells. Incubation time was $30 \mathrm{~min}$ or $60 \mathrm{~min}$. Data were statistically analyzed using $t$-test $(n=6, * * P<0.01, * * * P<0.001)$.

epithelium cells, potentially due to the binding of cRGD moiety on the polymers to the surface integrin receptors [65].

\section{Conclusions}

In summary, we have reported the direct synthesis of cRGD-functionalized polymers for the first time and quantitatively showed the targeting potential of these well-defined polymers. The method 
presented here can be easily applied to other acrylate/methacrylate monomers to obtain better building blocks for potential targeted drug delivery systems and offer an effective route to design and synthesis of targeted drug delivery systems for anticancer therapeutics.

\section{Acknowledgements}

H.T. acknowledges The Scientific and Technological Research Council of Turkey (TUBITAK-2216) for postdoctoral fellowship. The authors acknowledge NMR and mass spectroscopy facilities at Izmir Institute of Technology. The authors also acknowledge the Biotechnology and Bioengineering Research and Application Centre at Izmir Institute of Technology for providing the cell culture and flow cytometry facilities.

\section{Appendix A. Supplementary material}

Supplementary data associated with this article can be found, in the online version, at https://doi.org/10.1016/j.eurpolymj.2018.04.025.

\section{References}

[1] S. Zitzmann, V. Ehemann, M. Schwab, Arginine-glycine-aspartic acid (RGD)-peptide binds to both tumor and tumor-endothelial cells in vivo, CancerRes. 62 (18) (2002) 5139-5143.

[2] X. Hu, X. Guan, J. Li, Q. Pei, M. Liu, Z. Xie, X. Jing, Hybrid polymer micelles capable of cRGD targeting and pH-triggered surface charge conversion for tumor selective accumulation and promoted uptake, Chem. Commun. 50 (65) (2014) 9188-9191.

[3] Y.H. Kim, J. Jeon, S.H. Hong, W.K. Rhim, Y.S. Lee, H. Youn, J.K. Chung, M.C. Lee, D.S. Lee, K.W. Kang, Tumor targeting and imaging using cyclic RGD-PEGylated gold nanoparticle probes with directly conjugated iodine-125, Small 7 (14) (2011) 2052-2060.

[4] Q. Xu, Y. Liu, S. Su, W. Li, C. Chen, Y. Wu, Anti-tumor activity of paclitaxel through dual-targeting carrier of cyclic RGD and transferrin conjugated hyperbranched copolymer nanoparticles, Biomaterials 33 (5) (2012) 1627-1639.

[5] S. Liu, Radiolabeled cyclic RGD peptide bioconjugates as radiotracers targeting multiple integrins, Bioconj. Chem. 26 (8) (2015) 1413-1438.

[6] J. Morlieras, S. Dufort, L. Sancey, C. Truillet, A. Mignot, F. Rossetti, M. Dentamaro, S. Laurent, L. Vander Elst, R.N. Muller, Functionalization of small rigid platforms with cyclic RGD peptides for targeting tumors overexpressing av $\beta 3$-integrins, Bioconj. Chem. 24 (9) (2013) 1584-1597.

[7] M. Amin, M. Mansourian, G.A. Koning, A. Badiee, M.R. Jaafari, T.L. ten Hagen, Development of a novel cyclic RGD peptide for multiple targeting approaches of liposomes to tumor region, J. Control. Release 220 (2015) 308-315.

[8] H.-Q. Yin, F.-L. Bi, F. Gan, Rapid synthesis of cyclic RGD conjugated gold nanoclusters for targeting and fluorescence imaging of melanoma A375 cells, Bioconj. Chem. 26 (2) (2015) 243-249.

[9] Y. Sakurai, H. Hatakeyama, Y. Sato, M. Hyodo, H. Akita, N. Ohga, K. Hida, H. Harashima, RNAi-mediated gene knockdown and anti-angiogenic therapy of RCCs using a cyclic RGD-modified liposomal-siRNA system, J. Control. Release 173 (2014) 110-118.

[10] X. Guan, X. Hu, S. Liu, Y. Huang, X. Jing, Z. Xie, Cyclic RGD targeting nanoparticles with $\mathrm{pH}$ sensitive polymer-drug conjugates for effective treatment of melanoma, RSC Adv. 4 (98) (2014) 55187-55194.

[11] G. Gasparini, P.C. Brooks, E. Biganzoli, P.B. Vermeulen, E. Bonoldi, L.Y. Dirix, G. Ranieri, R. Miceli, D.A. Cheresh, Vascular integrin alpha (v) beta3: a new prognostic indicator in breast cancer, Clin. Cancer Res. 4 (11) (1998) 2625-2634.

[12] S.M. Albelda, S.A. Mette, D.E. Elder, R. Stewart, L. Damjanovich, M. Herlyn, C.A. Buck, Integrin distribution in malignant melanoma: association of the $\beta 3$ subunit with tumor progression, Cancer Res. 50 (20) (1990) 6757-6764.

[13] A. Gupta, W. Cao, M.A. Chellaiah, Integrin avß3 and CD44 pathways in metastatic prostate cancer cells support osteoclastogenesis via a Runx2/Smad 5/receptor activator of NF-кB ligand signaling axis, Mol. cancer 11 (1) (2012) 66.

[14] B. Felding-Habermann, T.E. O'Toole, J.W. Smith, E. Fransvea, Z.M. Ruggeri, M.H. Ginsberg, P.E. Hughes, N. Pampori, S.J. Shattil, A. Saven, Integrin activation controls metastasis in human breast cancer, Proc. Natl. Acad. Sci. 98 (4) (2001) 1853-1858.

[15] M. Rolli, E. Fransvea, J. Pilch, A. Saven, B. Felding-Habermann, Activated integrin avß3 cooperates with metalloproteinase MMP-9 in regulating migration of metastatic breast cancer cells, Proc. Natl. Acad. Sci. 100 (16) (2003) 9482-9487.

[16] B. Delouvrié, K. Al-Kadhimi, J.-C. Arnould, S.T. Barry, D.A. Cross, M. Didelot, P.R. Gavine, H. Germain, C.S. Harris, A.M. Hughes, Structure-activity relationship of a series of non peptidic RGD integrin antagonists targeting $\alpha 5 \beta$ 1: Part 1, Bioorg. Med. Chem. Lett. 22 (12) (2012) 4111-4116.

[17] Z. Chen, J. Deng, Y. Zhao, T. Tao, Cyclic RGD peptide-modified liposomal drug delivery system: enhanced cellular uptake in vitro and improved pharmacokinetics in rats, Int. J. Nanomed. 7 (2012) 3803.

[18] C. Chen, Z. Duan, Y. Yuan, R. Li, L. Pang, J. Liang, X. Xu, J. Wang, Peptide-22 and cyclic RGD functionalized liposomes for glioma targeting drug delivery overcoming
BBB and BBTB, ACS Appl. Mater. interfaces 9 (7) (2017) 5864-5873.

[19] M. Saraswathy, G.T. Knight, S. Pilla, R.S. Ashton, S. Gong, Multifunctional drug nanocarriers formed by cRGD-conjugated BCD-PAMAM-PEG for targeted cancer therapy, Colloids Surf. B Biointerfaces 126 (2015) 590-597.

[20] X. He, C.S. Alves, N. Oliveira, J. Rodrigues, J. Zhu, I. Bányai, H. Tomás, X. Shi, RGD peptide-modified multifunctional dendrimer platform for drug encapsulation and targeted inhibition of cancer cells, Colloids Surf. B Biointerfaces 125 (2015) 82-89.

[21] Z. Song, Y. Lin, C.F. Xia Zhang, Y. Lu, Y. Gao, C. Dong, Cyclic RGD peptide-modified liposomal drug delivery system for targeted oral apatinib administration: enhanced cellular uptake and improved therapeutic effects, Int. J. Nanomed. 12 (2017) 1941.

[22] Y. Zheng, S. Ji, A. Czerwinski, F. Valenzuela, M. Pennington, S. Liu, FITC-conjugated cyclic RGD peptides as fluorescent probes for staining integrin $\alpha v \beta 3 / \alpha v \beta 5$ in tumor tissues, Bioconj. Chem. 25 (11) (2014) 1925-1941.

[23] X. Guan, X. Guan, H. Tong, J. Ma, X. Sun, Target delivery of daunorubicin to glioblastoma by cyclic RGD-linked PEG-PLA micelles, J. Macromol. Sci., Part A 52 (5) (2015) 401-406.

[24] J. Kim, H.Y. Nam, J.W. Choi, C.-O. Yun, S.W. Kim, Efficient lung orthotopic tumor growth suppression of oncolytic adenovirus complexed with RGD-targeted bioreducible polymer, Gene Ther. 21 (5) (2014) 476.

[25] K. Zheng, N. Liang, J. Zhang, L. Lang, W. Zhang, S. Li, J. Zhao, G. Niu, F. Li, Z. Zhu, 68Ga-NOTA-PRGD2 PET/CT for integrin imaging in patients with lung cancer, J. Nucl. Med. 56 (12) (2015) 1823-1827.

[26] Y. Miura, T. Takenaka, K. Toh, S. Wu, H. Nishihara, M.R. Kano, Y. Ino, T. Nomoto, Y. Matsumoto, H. Koyama, Cyclic RGD-linked polymeric micelles for targeted delivery of platinum anticancer drugs to glioblastoma through the blood-brain tumor barrier, ACS Nano 7 (10) (2013) 8583-8592.

[27] A.J. Li, Y.H. Zheng, G.D. Liu, W.S. Liu, P.C. Cao, Z.F. Bu, Efficient delivery of docetaxel for the treatment of brain tumors by cyclic RGD-tagged polymeric micelles, Mol. Med. Rep. 11 (4) (2015) 3078-3086.

[28] P. Loyer, W. Bedhouche, Z.W. Huang, S. Cammas-Marion, Degradable and biocompatible nanoparticles decorated with cyclic RGD peptide for efficient drug delivery to hepatoma cells in vitro, Int. J. Pharmaceutics 454 (2) (2013) 727-737.

[29] Y. Xiao, H. Hong, V.Z. Matson, A. Javadi, W. Xu, Y. Yang, Y. Zhang, J.W. Engle, R.J. Nickles, W. Cai, Gold nanorods conjugated with doxorubicin and cRGD for combined anticancer drug delivery and PET imaging, Theranostics 2 (8) (2012) 757.

[30] X. Jiang, X. Sha, H. Xin, L. Chen, X. Gao, X. Wang, K. Law, J. Gu, Y. Chen, Y. Jiang, Self-aggregated pegylated poly (trimethylene carbonate) nanoparticles decorated with c (RGDyK) peptide for targeted paclitaxel delivery to integrin-rich tumors, Biomaterials 32 (35) (2011) 9457-9469.

[31] D. Gyawali, J.P. Kim, J. Yang, Highly photostable nanogels for fluorescence-based theranostics, Bioact. Mater. (2017).

[32] C. Wang, B. Chen, M. Zou, G. Cheng, Cyclic RGD-modified chitosan/graphene oxide polymers for drug delivery and cellular imaging, Colloids Surf. B Biointerfaces 122 (2014) 332-340.

[33] N. Anwar, A. Rix, W. Lederle, A.J. Kuehne, RGD-decorated conjugated polymer particles as fluorescent biomedical probes prepared by Sonogashira dispersion polymerization, Chem. Commun. 51 (45) (2015) 9358-9361.

[34] J. Liu, Q. Liu, C. Yang, Y. Sun, Y. Zhang, P. Huang, J. Zhou, Q. Liu, L. Chu, F. Huang, cRGD-modified benzimidazole-based pH-responsive nanoparticles for enhanced tumor targeted doxorubicin delivery, ACS Appl. Mater. Interfaces 8 (17) (2016) 10726-10736.

[35] Y. Chen, W. Zhang, Y. Huang, F. Gao, X. Fang, Dual-functional c (RGDyK)-decorated Pluronic micelles designed for antiangiogenesis and the treatment of drug-resistan tumor, Int. J. Nanomed. 10 (2015) 4863.

[36] I. Ozer, A. Tomak, H.M. Zareie, Y. Baran, V. Bulmus, Effect of molecular architecture on cell interactions and stealth properties of PEG, Biomacromolecules 18 (9) (2017) 2699-2710.

[37] E.M. Pelegri-O'Day, H.D. Maynard, Controlled radical polymerization as an enabling approach for the next generation of protein-polymer conjugates, Acc. Chem. Res. 49 (9) (2016) 1777-1785.

[38] Y. Qi, A. Chilkoti, Growing polymers from peptides and proteins: a biomedical perspective, Polym. Chem. 5 (2) (2014) 266-276.

[39] J. Collins, J. Tanaka, P. Wilson, K. Kempe, T.P. Davis, M.P. McIntosh, M.R. Whittaker, D.M. Haddleton, In situ conjugation of dithiophenol maleimide polymers and oxytocin for stable and reversible polymer-peptide conjugates, Bioconj. Chem. 26 (4) (2015) 633-638.

[40] B.D. Mather, J.R. Lizotte, T.E. Long, Synthesis of chain end functionalized multiple hydrogen bonded polystyrenes and poly (alkyl acrylates) using controlled radical polymerization, Macromolecules 37 (25) (2004) 9331-9337.

[41] G. Mantovani, F. Lecolley, L. Tao, D.M. Haddleton, J. Clerx, J.J. Cornelissen, K. Velonia, Design and synthesis of N-maleimido-functionalized hydrophilic polymers via copper-mediated living radical polymerization: a suitable alternative to PEGylation chemistry, J. Am. Chem. Soc. 127 (9) (2005) 2966-2973.

[42] C. Boyer, V. Bulmus, J. Liu, T.P. Davis, M.H. Stenzel, C. Barner-Kowollik, Welldefined protein - polymer conjugates via in situ RAFT polymerization, J. Am. Chem. Soc. 129 (22) (2007) 7145-7154.

[43] J.T. Lai, R. Shea, Controlled radical polymerization by carboxyl-and hydroxyl-terminated dithiocarbamates and xanthates, J. Polym. Sci., Part A: Polym. Chem. 44 (14) (2006) 4298-4316.

[44] J. Liu, C.-Y. Hong, C.-Y. Pan, Dihydroxyl-terminated telechelic polymers prepared by RAFT polymerization using functional trithiocarbonate as chain transfer agent, Polymer 45 (13) (2004) 4413-4421.

[45] S. Carter, B. Hunt, S. Rimmer, Highly branched poly (N-isopropylacrylamide) s with imidazole end groups prepared by radical polymerization in the presence of a styry monomer containing a dithioester group, Macromolecules 38 (11) (2005) 
4595-4603.

[46] X. Huang, S.İ. Sevimli, V. Bulmus, pH-labile sheddable block copolymers by RAFT polymerization: synthesis and potential use as siRNA conjugates, Eur. Polym. J. 49 (10) (2013) 2895-2905.

[47] C.-Y. Hong, C.-Y. Pan, Direct synthesis of biotinylated stimuli-responsive polymer and diblock copolymer by RAFT polymerization using biotinylated trithiocarbonate as RAFT agent, Macromolecules 39 (10) (2006) 3517-3524.

[48] M. Bathfield, F. D'Agosto, R. Spitz, M.-T. Charreyre, T. Delair, Versatile precursors of functional RAFT agents. Application to the synthesis of bio-related end-functionalized polymers, J. Am. Chem. Soc. 128 (8) (2006) 2546-2547.

[49] G. Moad, Y. Chong, A. Postma, E. Rizzardo, S.H. Thang, Advances in RAFT polymerization: the synthesis of polymers with defined end-groups, Polymer 46 (19) (2005) 8458-8468.

[50] D. Pissuwan, C. Boyer, K. Gunasekaran, T.P. Davis, V. Bulmus, In vitro cytotoxicity of RAFT polymers, Biomacromolecules 11 (2) (2010) 412-420.

[51] C. Boyer, A. Granville, T.P. Davis, V. Bulmus, Modification of RAFT-polymers via thiol-ene reactions: a general route to functional polymers and new architectures, J. Polym. Sci., Part A: Polym. Chem. 47 (15) (2009) 3773-3794.

[52] C. Boyer, J. Liu, V. Bulmus, T.P. Davis, RAFT polymer end-group modification and chain coupling/conjugation via disulfide bonds, Austr. J. Chem. 62 (8) (2009) 830-847.

[53] K. Berg, M.B. Hansen, S.E. Nielsen, A new sensitive bioassay for precise quantification of interferon activity as measured via the mitochondrial dehydrogenase function in cells (MTT-method), Apmis 98 (1-6) (1990) 156-162.

[54] P. Huang, H. Song, W. Wang, Y. Sun, J. Zhou, X. Wang, J. Liu, J. Liu, D. Kong, A. Dong, Integrin-targeted zwitterionic polymeric nanoparticles with acid-induced disassembly property for enhanced drug accumulation and release in tumor, Biomacromolecules 15 (8) (2014) 3128-3138.

[55] K. Gunasekaran, T.H. Nguyen, H.D. Maynard, T.P. Davis, V. Bulmus, Conjugation of
siRNA with comb-type PEG enhances serum stability and gene silencing efficiency, Macromol. Rapid Commun. 32 (8) (2011) 654-659.

[56] X. Huang, C. Boyer, T.P. Davis, V. Bulmus, Synthesis of heterotelechelic polymers with affinity to glutathione-S-transferase and biotin-tagged proteins by RAFT polymerization and thiol-ene reactions, Polym. Chem. 2 (7) (2011) 1505-1512.

[57] S. Sevimli, F. Inci, H.M. Zareie, V. Bulmus, Well-defined cholesterol polymers with pH-controlled membrane switching activity, Biomacromolecules 13 (10) (2012) 3064-3075.

[58] G. Moad, E. Rizzardo, S.H. Thang, Living radical polymerization by the RAFT process-a third update, Aust. J. Chem. 65 (8) (2012) 985-1076.

[59] G. Moad, E. Rizzardo, S.H. Thang, End-functional polymers, thiocarbonylthio group removal/transformation and reversible addition-fragmentation-chain transfer (RAFT) polymerization, Polym. Int. 60 (1) (2011) 9-25.

[60] C. Boyer, V. Bulmus, T.P. Davis, V. Ladmiral, J. Liu, S. Perrier, Bioapplications of RAFT polymerization, Chem. Rev. 109 (11) (2009) 5402-5436.

[61] J. Folkman, Angiogenesis in cancer, vascular, rheumatoid and other disease, Nat. Med. 1 (1) (1995) 27.

[62] Z. Wen, Q. Jia, X. Kang, Y. Lou, L. Zou, J. Yang, J. Gao, L. Han, X. Li, Antitumor

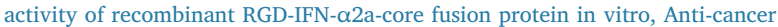
Drugs 28 (1) (2017) 31.

[63] R.G. Cox, S.B. Livesay, M. Johnson, M.D. Ohi, J.V. Williams, The human metapneumovirus fusion protein mediates entry via an interaction with RGD-binding integrins, J. Virol. 86 (22) (2012) 12148-12160.

[64] O. Heikkilä, P. Susi, G. Stanway, T. Hyypiä, Integrin $\alpha$ VB6 is a high-affinity receptor for coxsackievirus A9, J. Gen. Virol. 90 (1) (2009) 197-204.

[65] A.R. Hsu, A. Veeravagu, W. Cai, L.C. Hou, V. Tse, X. Chen, Integrin $\alpha v \beta 3$ antagonists for anti-angiogenic cancer treatment, Recent patents Anti-cancer Drug Discov. 2 (2) (2007) 143-158. 